\title{
COBALT AND MOLYBDENUM CONCENTRATED SUSPENSION FOR SOYBEAN SEED TREATMENT ${ }^{(1)}$
}

\author{
Regina Maria Quintão Lana ${ }^{(2)}$, Marcos Vieira de Faria ${ }^{(3)}$, Ivan \\ Bonotto $^{(4)}$ \& Ângela Maria Quintão Lana ${ }^{(5)}$
}

\begin{abstract}
The concentrated suspension (CS), the basis of Mo trioxide, allows high Mo concentrations and is therefore a technical advance for seed treatment, since it allows the recommendation of the Mo at lower dosage than with the liquid solution formulations (LS). The purpose of this research was to evaluate the efficiency and doses of fertilizer with Mo and Co in concentrated suspension in comparison with liquid solution as well as fertilizers associated with phytohormones, applied in seed treatments, and their effect on soybean yield. Two experiments were carried out in the growing seasons of 2004/2005 and 2005/2006 at the Universidade Federal de Uberlandia (UFU).The first was conducted in an experimental area on the Fazenda Capim Branco, with six treatments and four replications: (1) Mo and Co (CS) $-22 \mathrm{~g} \mathrm{ha}^{-1}+1.08 \mathrm{~g} \mathrm{ha}^{-1}$; (2) Mo and Co (CS) $-22 \mathrm{~g} \mathrm{ha}^{-1}++1.08 \mathrm{~g} \mathrm{ha}^{-1}+$ phytohormone -200 $\mathrm{mL} \mathrm{ha}^{-1}$; 3) Mo and Co (LS), $20.7 \mathrm{~g} \mathrm{ha}^{-1}+4.13 \mathrm{~g} \mathrm{ha}^{-1}$; 4) Mo and Co (LS), $20.7 \mathrm{~g} \mathrm{ha}^{-1}+4.13 \mathrm{~g} \mathrm{ha}^{-1}+$ phytohormone $-200 \mathrm{~mL} \mathrm{ha}^{-1}$; (5) + control phytohormone-200 $\mathrm{mL} \mathrm{ha}{ }^{-1}$; and (6) control (free of Mo and Co in the seed treatment). The phytohormone consisted of: auxin $\left(11 \mathrm{mg} \mathrm{L}^{-1}\right)$ and cytokynin $\left(0.031 \mathrm{mg} \mathrm{L}^{-1}\right)$. The soybean cultivar Monsoy 8004 was used and a fertilization of $400 \mathrm{~kg} \mathrm{ha}^{-1}$ of 02-20-20 NPK fertilizer was applied at sowing. Based on the results of the first experiment, the second was conducted on the Fazenda Floresta do Lobo, in Uberlândia, MG, evaluated in a randomized block design with nine treatments and four replications. The treatments consisted of Mo and Co ( $\left.\mathrm{g} \mathrm{ha}^{-1}\right)$ doses applied to soybean seeds, as CS formulation $(15,25,35,45,60$ and $0.74 ; 1.23$; $1.72 ; 2.21 ; 2.95)$ and LS- $(15 ; 20 ; 25$ and $3.18 ; 4.25 ; 5.31)$, respectively, and the control (free of Mo and Co in the seed treatment). The variety Monarch was used, fertilized
\end{abstract}

\footnotetext{
(1) Work carried out with financial support from the Compo do Brazil S.A. Received for publication in November 2007 and aproved in July 2009 .

(2) Professor at the Federal University of Uberlândia - UFU. Caixa Postal 593, CEP 38400-902 Uberlândia (MG). E-mail: rmqlana@iciag.ufu.br

${ }^{(3)}$ Master in Agronomy. E-mail: marcosvfagro@gmail.com

(4) MSc in Agronomy, UFU. E-mail: ivanbonotto@terra.com.br

(5) Associate Professor, Department of Animal Husbandry, EV - UFMG. Av. Presidente Antônio Carlos 6.627, Campus da UFMG, Pampulha, CEP 31270-901 Belo Horizonte (MG). E-mail: lana@vet.ufmg.br
} 
with $300 \mathrm{~kg} \mathrm{ha}^{-1}$ of NPK fertilizer (03-32-06) at sowing; and $78 \mathrm{~kg} \mathrm{ha}^{-1}\left(\mathrm{~K}_{2} \mathrm{O}\right)$ in topdressing 30 days after soybean emergence. The Mo and Co doses in the seed treatment with LS and CS resulted in higher soybean yields than in the control, from $20 \mathrm{~g} \mathrm{ha}^{-1}$ Mo and $4.25 \mathrm{~g} \mathrm{ha}^{-1} \mathrm{Co}$ in liquid solution and $35 \mathrm{~g} \mathrm{ha}^{-1} \mathrm{Mo}$ and $1.72 \mathrm{~g} \mathrm{ha}^{-1}$ Co in the concentrated suspension .

Index terms: Glycine max, micronutrients, fertilizer technology, nutrition.

\title{
RESUMO: COBALTO E MOLIBDENNIO EM SUSPENSÃO CONCENTRADA NO TRATAMENTO DE SEMENTE EM SOJA
}

\begin{abstract}
A formulação suspensão concentrada (SC), que éà base de trióxido de Mo, permite altas concentrações de Mo por unidade de volume; é, portanto, um avanço tecnológico no tratamento de semente, pois há condições de obedecer à recomendação de Mo da Embrapa em volumes de dosagens menores que os produtos em formulação solução líquida(LS). Objetivou-se avaliar a eficácia de doses de fertilizantes contendo Co e Mo em formulação suspensão concentrada (CS) em comparação com a formulação solução líquida (LS), bem como a associação dos fertilizantes com fitormônio aplicados no tratamento de semente e o desempenho na produtividade da soja. Foram realizados dois experimentos, em dois anos consecutivos, nas safras de 2004 / 2005 e 2005/2006. O primeiro foi conduzido na área experimental da Fazenda Capim Branco, com seis tratamentos e quatro repetições: (1) Mo e Co (CS) - $22 \mathrm{~g} \mathrm{ha} \mathrm{a}^{-1}+$

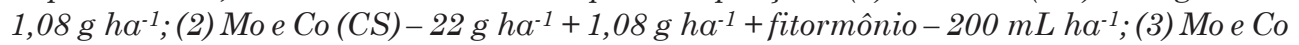

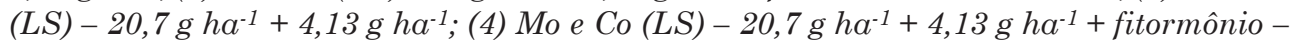

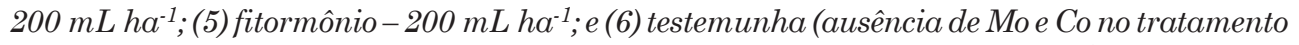
de sementes). A composição do fitormônio é à base de auxina (11 $\left.\mathrm{mg} \mathrm{L}^{-1}\right)$ e citocinina (0,031 $\left.\mathrm{mg} \mathrm{L}^{-1}\right)$. A cultivar de soja utilizada foi a Monsoy 8004, e a adubação de semeadura foi realizada com $400 \mathrm{~kg} \mathrm{ha}^{-1}$ da formulação 02-20-20. De posse dos resultados obtidos no primeiro experimento, foi realizado outro experimento na Fazenda Floresta do Lobo, localizada no municipio de Uberlândia, MG. O delineamento experimental foi de blocos casualizados, com nove tratamentos e quatro repetições. Foram aplicados, em tratamento de semente, nas doses em g ha-1 de Mo e Co: formulação CS - (15, 25, 35, 45, 60 e 0,74; 1,23; 1,72; 2,21; 2,95), respectivamente formulação $L S$ - (15; 20 e 25 e 3,18; 4,25; 5,31), respectivamente; e a testemunha (ausência de Mo e Co no tratamento de sementes). Utilizou-se a cultivar Monarca, com a adubação de semeadura de $300 \mathrm{~kg} \mathrm{ha}^{-1}$ do formulado 03-32-06; e adubação de cobertura com $78 \mathrm{~kg} \mathrm{ha} \mathrm{a}^{-1}$ de K2O, aos $30 \mathrm{DAE}$. As doses de Mo e Co no tratamento de semente com solução líquida e suspensão concentrada, aumentaram o rendimento de grãos de soja. A produtividade

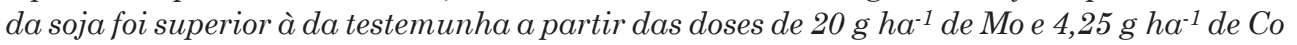

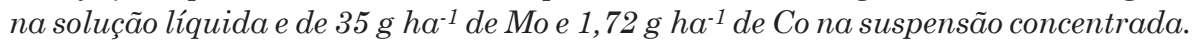

Termos de indexação: Glycine max, micronutrientes, tecnologia de fertilizantes, nutrição.

\section{INTRODUCTION}

The process of biological $\mathrm{N}_{2}$ fixation (BNF) is characterized by the conversion of atmospheric $\mathrm{N}_{2}$ into plant-available ammonia. Thus, according to (Embrapa, 2007), BNF is the main $\mathrm{N}$ source to soybean and can, depending on its efficiency, supply at least part of the soybean $\mathrm{N}$ demand.

Although plants require only small quantities of Mo, according to Gupta \& Lipsett (1981), this nutrient participates in plant growth and development by influencing $\mathrm{N}$ metabolism. It is a cofactor in the nitrogenase and nitrate reductase enzymes. Nitrogenase is essential for the symbiotic fixation of atmospheric
$\mathrm{N}_{2}$ and nitrate reductase is indispensable for the recovery of nitrate uptake by plants.

Cobalt in soybean is considered important for the N2-fixing microorganisms. It is a component of vitamin B12, taking part in the formation of the coenzyme cobamide which is essential in the process of FBN as a precursor of leghemoglobin. As a result, Co deficiency inhibits leghemoglobin synthesis and, therefore, BNF (Lopes \& Leonel Junior 2000).

According to Pessoa et al. (1999), since soybean requires only small amounts of Mo, application by seeds seems practical. Campo \& Hungria (2002) also recommend Co and Mo application via seeds, due to the efficiency, low cost and ease of application. 
Several studies have demonstrated the effectiveness of Mo-treated seeds. In experiments at three locations in Parana State, Sfredo et al. (1996) obtained increased yields on average $18-37 \%$, compared to a treatment that contained the inoculant only. They concluded that an addition of Mo to the commercial formulations resulted in higher yields. Furthermore, according to Campo \& Hungria (2002), even in highly fertile soils the response to the addition of Co and Mo was positive.

The following Co and Mo sources are used: Co chloride, Co sulfate, Co nitrate, sodium molybdate, ammonium molybdate, and Mo trioxide. Several commercial products on the market contain these elements at varying concentrations, but more commonly, in formulations with a 10:1 Mo/Co ratio. The results of supplying Mo and Co by these commercial products to the seed or by foliar application have been good (Campo \& Hungria, 2002).

In the seed treatment, the amount of liquid to be applied is restricted. According to Embrapa (2007), pesticides and nutrients in liquid form may be applied at up to $300 \mathrm{~mL}$ of fluid per $50 \mathrm{~kg}$ of seeds. Larger amounts of fluid can destroy the seed coat and hinder germination.

Currently, Co and Mo are used in liquid solution (LS) formulation, where Mo is derived from sodium molybdate, ammonium or $\mathrm{K}$ and $\mathrm{Co}$ from nitrate or chloride. These products are completely soluble and, with their physical and chemical characteristics, are not harmful to seeds and $\mathrm{N}_{2}$ fixing bacteria. However, the nutrient concentrations in liquid formulations require volumes ranging from 100 to $200 \mathrm{~mL} \mathrm{ha}^{-1}$, which may cause an excess of fluid for soybean seeds. Moreover, phytosanitary treatments and the application of inoculants to the seeds may be necessary (Lantmann, 2002).

New technologies such as concentrated suspension are being developed to establish formulations with high Co and Mo concentrations for applications at lower doses without causing problems related to liquid excess. The aqueous concentrated suspension contains a stable suspension of active ingredient, wetting agent, dispersant and suspensor. It is applied diluted in water.

Therefore, the aim of this study was to evaluate the efficacy and doses of fertilizers containing Co and Mo in concentrated suspension (CS) formulation and liquid solution (LS), as well as of the association of the fertilizer with phytohormone applied in the seed treatment, on soybean yield.

\section{MATERIALS AND METHODS}

Two experiments were conducted in 2004/2005 and 2005/2006. The first was a field experiment carried out in a no-till system on the Experimental Farm Capim Branco, in Uberlândia, State of Minas Gerais, with gentle slopes and $850 \mathrm{~m}$ altitude, $1523 \mathrm{~mm}$ rainfall, from November 2004 to April 2005.

The soil in the experimental area, analyzed prior to the experiment, was classified as Red Latosol. The chemical characteristics were $\mathrm{pH}(2: 1)=6.5$, available $\mathrm{P}=2.6 \mathrm{mg} \mathrm{dm}^{-3}$, available $\mathrm{K}=96.3 \mathrm{mg} \mathrm{dm}^{-3}$, available $\mathrm{S}=9.0 \mathrm{mg} \mathrm{dm}{ }^{-3}, \mathrm{Ca}=2.5 \mathrm{cmol}_{\mathrm{c}} \mathrm{dm}^{-3}$ and $\mathrm{Mg}=$ $1.4 \mathrm{cmol}_{\mathrm{c}} \mathrm{dm}^{-3}$, organic matter $(\mathrm{OM})=250 \mathrm{~g} \mathrm{~kg}^{-1} ;$ CEC at $\mathrm{pH} 7.0(\mathrm{~T})=6.28 \mathrm{cmolc} \mathrm{dm}^{-3}$ and base saturation (V) $=67.0 \%$. The following extraction methods were used: $\mathrm{P}, \mathrm{K}=\left(\mathrm{HCl} 0.05 \mathrm{~mol} \mathrm{~L}^{-1}+\mathrm{H}_{2} \mathrm{SO}_{4} \mathrm{~mol} \mathrm{~L}^{-1}\right)$, S$\mathrm{SO}_{4}{ }^{2-}=\mathrm{Ca}\left(\mathrm{H}_{2} \mathrm{PO}_{4}\right)_{2} 0.01 \mathrm{~mol} \mathrm{~L}{ }^{-1} ; \mathrm{Ca}^{2+}, \mathrm{Mg}^{2+}=(\mathrm{KCl}$ $\left.1 \mathrm{~mol} \mathrm{~L}^{-1}\right)$, MO = Colorimetric method. The micronutrient levels in the soil were determined as follows: $\mathrm{Mn}=2.1 \mathrm{mg} \mathrm{dm}-3, \mathrm{~B}=0.14 \mathrm{mg} \mathrm{dm}^{-3}$, $\mathrm{Zn}=0.7 \mathrm{mg} \mathrm{dm}^{-3}, \mathrm{Fe}=17 \mathrm{mg} \mathrm{dm}^{-3}$ and $\mathrm{Cu}=$ $7.1 \mathrm{mg} \mathrm{dm}^{-3}$, and the methods of extraction were: $\mathrm{B}=$ $\left[\mathrm{BaCl}_{2} .2 \mathrm{H}_{2} \mathrm{O} 0.125 \%\right.$ hot], $\mathrm{Cu}, \mathrm{Fe}, \mathrm{Mn}, \mathrm{Zn}=$ [DTPA $0.005 \mathrm{~mol} \mathrm{~L}^{-1}+\mathrm{CaCl} 0.01 \mathrm{~mol} \mathrm{~L}^{-1}+\mathrm{TEA} 0.1 \mathrm{~mol} \mathrm{~L}^{-1}$ at $\mathrm{pH}$ 7.3].

The experimental design consisted of randomized blocks with six treatments and four replications. The fertilizers for seed treatment with Co and Mo were used in two formulations: liquid solution (LS) based on salts (sodium molybdate and Co sulfate) and concentrated suspension (CS) based on Mo trioxide. The fertilizers had the following characteristics: Mo and $\mathrm{Co}$ in the CS formulation $(\mathrm{m} / \mathrm{m} \%-34.5 \% \mathrm{Mo}$ and $1.7 \% \mathrm{Co}$ ), density $1.6 \mathrm{~g} \mathrm{~cm}^{-3}$, Mo and Co in the LS formulation (m/m \% - $10 \%$ Mo and $2 \%$ Co), density $1.38 \mathrm{~g} \mathrm{~cm}^{-3}$, and phytohormone based on auxin $\left(11 \mathrm{mg} \mathrm{L}^{-1}\right)$ and cytokinin $\left(0.031 \mathrm{mg} \mathrm{L}^{-1}\right)$. The doses of Mo and Co in the seed treatment in $\mathrm{g} \mathrm{ha}^{-1}$ were: (1) Mo and Co (CS) - $22 \mathrm{~g} \mathrm{ha}^{-1}+1.08 \mathrm{~g} \mathrm{ha}^{-1}$, (2) Mo and Co (CS) - $22 \mathrm{~g} \mathrm{ha}^{-1}+1.08 \mathrm{~g} \mathrm{ha}^{-1}+$ phytohormone $200 \mathrm{~mL} \mathrm{ha}^{-1}$, (3) Mo and Co (LS) - $20.7 \mathrm{~g} \mathrm{ha}^{-1}+$ $4.13 \mathrm{~g} \mathrm{ha}^{-1}$, (4) Mo and Co (LS) - $20.7 \mathrm{~g} \mathrm{ha}^{-1}+$ $4.13 \mathrm{~g} \mathrm{ha}^{-1}$ phytohormone - $200 \mathrm{~mL} \mathrm{ha}^{-1}$; (5) phytohormone - $200 \mathrm{~mL} \mathrm{ha}^{-1}$; and (6) control (absence of Mo and Co in seed treatment).

Each plot consisted of six $6 \mathrm{~m}$ row, spaced $45 \mathrm{~cm}$. The cultivar Monsoy 8004 was used, sown by hand on 28 November 2004. Fertilizer was applied at an amount of $400 \mathrm{~kg} \mathrm{ha}^{-1}$ NPK fertilizer 02-20-20, according to Embrapa (2004).

Based on the results of the first experiment, the second part was carried out on the Fazenda Floresta do Lobo, owned by the company Pinusplan in Uberlândia-MG, at an altitude of $900 \mathrm{~m}$, with 1531 $\mathrm{mm}$ rainfall. The experiment took place from October 2005 to April 2006.

The soil in the experimental area was classified as Red Yellow Latosol with clay texture. Soil analysis prior to the experiment determined the chemical properties in the top layer of $0-20 \mathrm{~cm}$ as follows: $\mathrm{pH}$ 
$(2: 1)=5.3$, available $\mathrm{P}=22.6 \mathrm{mg} \mathrm{dm}^{-3}$, available $\mathrm{K}=100 \mathrm{mg} \mathrm{dm}^{-3}$ available $\mathrm{S}=38 \mathrm{mg} \mathrm{dm}^{-3}, \mathrm{Ca}=$ $1.8 \mathrm{cmol}_{\mathrm{c}} \mathrm{dm}^{-3}$, and $\mathrm{Mg}=0.6 \mathrm{cmol}_{\mathrm{c}} \mathrm{dm}^{-3}$, organic matter $=280 \mathrm{~g} \mathrm{~kg}^{-1}$; CEC at pH $7.0(\mathrm{~T})=6.9 \mathrm{cmol}_{\mathrm{c}} \mathrm{cm}^{-3}$ and base saturation $(\mathrm{V})=39.0 \%$. The soil micronutrients levels were measured as follows: $\mathrm{Mn}=2.3 \mathrm{mg} \mathrm{dm}^{-3}$, $\mathrm{B}=0.07 \mathrm{mg} \mathrm{dm}^{-3}, \mathrm{Zn}=2.7 \mathrm{mg} \mathrm{dm}^{-3}, \mathrm{Fe}=63 \mathrm{mg} \mathrm{dm}^{-3}$ and $\mathrm{S}=1.3 \mathrm{mg} \mathrm{dm}^{-3}$. The soil was analyzed using the same methods as in the previous experiment.

The experimental design consisted of randomized blocks with nine treatments and four replications. Seeds were treated with Mo and Co in doses of $\mathrm{g} \mathrm{ha}^{-1}$ with: CS formulation $(15,25,35,45,60$ and 0.74 , $1.23,1.72,2.21 ; 2.95)$, LS formulation (15, 20, 25 and $3.18,4.25,5.31$ ) and control (no Mo and Co in the seed treatment). The plots consisted of $6 \mathrm{~m}$ long rows spaced $0.50 \mathrm{~m}$ apart and $1 \mathrm{~m}$ between the blocks; the four central rows were considered in the evaluations.

For the seed treatment with Co and Mo two fertilizer formulations were applied: liquid solution (LS) based on salts (Na molybdate and Co sulfate) and concentrated suspension (CS), based on Mo trioxide. The LS was applied as recommended by Embrapa (2007) for seed treatments, at doses of $2-$ $3 \mathrm{~g} \mathrm{ha}^{-1}$ Co and 12-25 $\mathrm{g} \mathrm{ha}^{-1}$ Mo. A concentrated suspension (CS) can contain high Mo concentrations, which represents a technological breakthrough in seed treatment. With concentrated suspension, the recommendation of Embrapa for Mo can be met, using lower doses than with the standard products in LS.

The fertilizers had the following properties: Mo and Co in the CS formulation $(\mathrm{m} / \mathrm{m} \%-34.5 \%$ Mo and $1.7 \%$ Co), density $1.6 \mathrm{~g} \mathrm{~cm}^{-3}$ and Mo and Co in LS formulation (m/m \% - $10 \%$ Mo and $2 \% \mathrm{Co})$, density $1.38 \mathrm{~g} \mathrm{~cm}^{-3}$. Cultivar Monarca was used, sown on 14 November 2005. The seeds were treated with fungicide Vitavax in doses from $0.2-0.3 \mathrm{~L}$ per $100 \mathrm{~kg}$ of seeds. Fertilization was applied according to the CFSEMG recommendation, using $300 \mathrm{~kg} \mathrm{ha}^{-1}$ of 03-32-06, (1999). Fertilization took place 30 days after soybean emergence with $78 \mathrm{~kg} \mathrm{ha}{ }^{-1}\left(\mathrm{~K}_{2} \mathrm{O}\right) \mathrm{KCl}$. Weeds, pests and diseases were controlled as required by the crop.

To assess the foliar $\mathrm{N}$ and micronutrients concentration, samples were collected by removing the third leaf from the apex of the main plant stem with the petiole during soybean flowering. These leaves were analyzed according to Bataglia et al. (1983) at the Soil Laboratory of the Institute of Agricultural Sciences of the UFU. The following variables were evaluated: yield, leaf $\mathrm{N}$, other nutrients and 1000 grain weight.

The variance of data for yield, 1000 grain weight, $\mathrm{N}$ and other nutrient contents were analyzed using the Program for Statistical Analysis - SANEST and the means compared by the Tukey test (significance $5 \%$ ). Yield data were also submitted to regression analysis.

\section{RESULTS AND DISCUSSION}

The differences between the treatments and the control were significant, whereas the treatments did not differ significantly from each other (Table 1). The application of $22 \mathrm{~g} \mathrm{ha}^{-1} \mathrm{Mo}+1.08 \mathrm{~g} \mathrm{ha}^{-1}$ Co in CS resulted in a yield of $5,905 \mathrm{~kg} \mathrm{ha}^{-1}$ soybean - $32 \%$ more than of the control $\left(4,442 \mathrm{~kg} \mathrm{ha}^{-1}\right)$ - while the application of $20.7 \mathrm{~g} \mathrm{ha}^{-1} \mathrm{Mo}+4.13 \mathrm{~g} \mathrm{ha}^{-1}$ Co in LS resulted in a $19 \%$ higher grain yield than of the control (Table 1).

A linear model of increasing soybean yield shows the effect of Mo and Co after treating seeds with concentrated suspension (Figure 1). For each $1 \mathrm{~g} \mathrm{ha}^{-1}$ Mo and $0.05 \mathrm{~g} \mathrm{ha}^{-1}$ Co applied, an increase of $20.74 \mathrm{~kg} \mathrm{ha}^{-1}$ of soybean is expected, up to a dose of $60 \mathrm{~g} \mathrm{ha}^{-1}$ Mo.

The response of soybean to seed treatment by doses of liquid solution shows a linear increase (Figure 2). For each $1 \mathrm{~g} \mathrm{ha}^{-1}$ Mo and $0.2 \mathrm{~g} \mathrm{ha}^{-1}$ Co applied, an increase of $42.54 \mathrm{~kg} \mathrm{ha}^{-1}$ of soybean is expected, up to a dose of $25 \mathrm{~g} \mathrm{ha}^{-1} \mathrm{Mo}$.

Table 1. Mean grain yield of soybean treated with molybdenum in concentrated suspension formulation, liquid solution and phytohormone at different levels in 2004/2005

\begin{tabular}{lc}
\hline \multicolumn{1}{c}{ Treatment } & Productivity \\
\hline & $\mathrm{kg} \mathrm{ha}^{-1}$ \\
$22 \mathrm{~g} \mathrm{ha}^{-1}$ of Mo $+1,08$ of Co CS & $5,905 \mathrm{a}$ \\
$22 \mathrm{~g} \mathrm{ha}^{-1}$ of Mo SC & \\
phytohormone $\left(200 \mathrm{~mL} \mathrm{ha}^{-1}\right)$ & $5,754 \mathrm{a}$ \\
$20,7 \mathrm{~g} \mathrm{ha}^{-1}$ of Mo $+4,13$ of Co SL & \\
$20,7 \mathrm{~g} \mathrm{ha}^{-1}$ of Mo $+4,13$ of Co SL $^{(2)}+$ & $5,301 \mathrm{a}$ \\
phytohormone $\left(200 \mathrm{~mL} \mathrm{ha}^{-1}\right)$ & $6,008 \mathrm{a}$ \\
Phytohormone $\left(200 \mathrm{~mL} \mathrm{ha}{ }^{-1}\right)$ & $5,620 \mathrm{a}$ \\
Control & $4,442 \mathrm{~b}$ \\
LSD $5 \%$ & 804.06 \\
CV $\%)$ & 6.25 \\
\hline
\end{tabular}

(1) CS: concentrated suspension formulation. ${ }^{(2)}$ LS: Liquid solution formulation. Averages followed by the same letter in the column do not differ significantly by the Tukey test at $5 \%$.

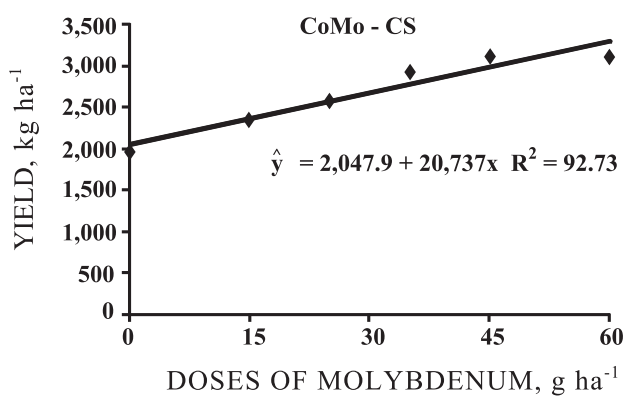

Figure 1. Soybean grain yield as related to seed treatments with Mo and Co doses in concentrated suspension . 
There is difference in productivity of soybean treated with LS and CS formulation due to the application of different Mo doses (Table 2). The yield of the control was lowest - $1,967 \mathrm{~kg} \mathrm{ha}^{-1}$ - indicating the importance of Co and Mo application to soybean. According to Campo \& Hungria (2002), even fertile soil showed a positive response to the addition of $\mathrm{Co}$ and Mo. According to Pessoa et al. (1999), the Mo quantities required for soybean are small, favoring an application of this element along with a seed inoculant. The occurrence of $\mathrm{N}_{2}$ fixation in soils with optimum fertility conditions results in high soybean yields. In this context, the influence of Mo, which also participates in nitrate reductase, is remarkable. It is responsible for the reduction of $\mathrm{NO}_{3}{ }^{-}$for $\mathrm{N}$ plant assimilation (Marschner, 1986).

Yields were highest in the treatments with concentrated suspension at doses of 45 and $60 \mathrm{~g} \mathrm{ha}^{-1}$ Mo $-3,114 \mathrm{~kg} \mathrm{ha}^{-1}$ and $3,112 \mathrm{~kg} \mathrm{ha}^{-1}$, respectively (Table 2). The control yield did not differ regarding the application of $15 \mathrm{~g} \mathrm{ha}^{-1}$ Mo in concentrated suspension. The responses to Mo fertilization in Brazil are not consistent. Several experiments with soybean did not show yield increases (Lám-Sanchez \& Awad, 1976; Kolling et al., 1981). However, significant increases were reported by Buzetti et al.

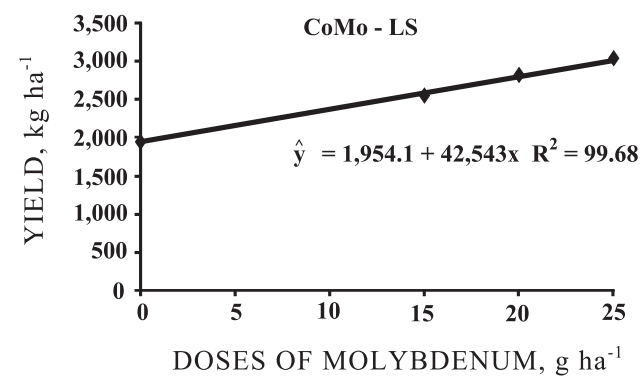

Figure 2. Soybean yield as related to seed treatments with Mo and Co doses in liquid solution in 2005/ 2006.
(1981) and Bellintani Neto \& Lám-Sanchez (1974) in response to fertilization with $400 \mathrm{~g} \mathrm{ha}^{-1}$ of Na molybdate on Dark Red Latosol. Similarly, Vitti et al. (1984) reported increases of up to $32.7 \%$ with doses of a commercial product containing $10 \% \mathrm{Mo}$ and $1 \%$ Co.

Treatments with liquid solution showed an increase at rates of $20 \mathrm{~g} \mathrm{ha}^{-1}$ Mo and more (Table 2). Treatments with concentrated suspension resulted in a better performance at rates of $35 \mathrm{~g} \mathrm{ha}^{-1}$ Mo and higher (Table 2).

A comparison of the performance between the formulations at the same doses ( 15 and $25 \mathrm{~g} \mathrm{ha}^{-1}$ ) showed differences between them: yields were higher with application of liquid solution at $25 \mathrm{~g} \mathrm{ha}^{-1} \mathrm{Mo}$ (Table 2). The mean weight of 1,000 grains (Table 2) did not differ between treatments.

There were no differences between treatments in $\mathrm{N}$ and nutrient content (Table 3).

Table 2. Mean yield of soybean and mean weight of 1000 grains (PMG) at different Mo and Co doses in concentrated suspension and liquid solution in $2005 / 2006$

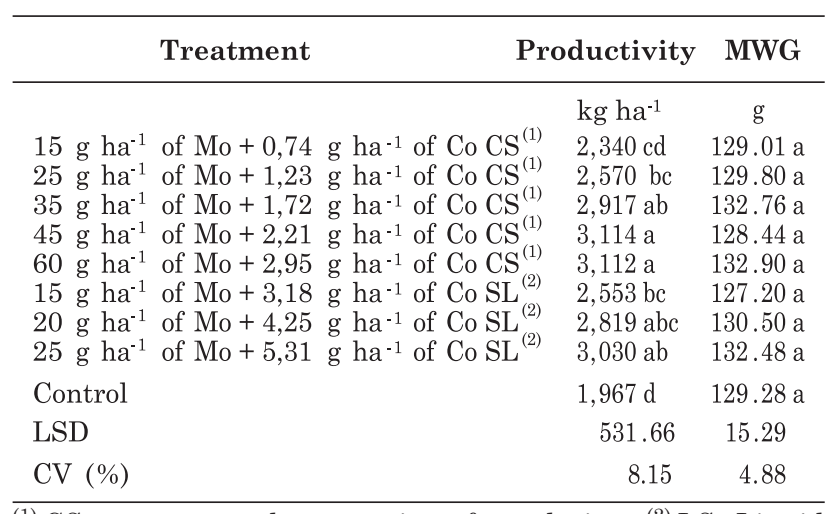

(1) CS: concentrated suspension formulation. ${ }^{(2)}$ LS: Liquid solution formulation. Means followed by the same letter in a column do not differ significantly by the Tukey test at $5 \%$.

Table 3. Mean leaf nitrogen and micronutrients in soybean after application of different Mo and Co doses in concentrated suspension and liquid solution in 2005/2006

\begin{tabular}{|c|c|c|c|c|c|c|}
\hline Tratament & $\mathbf{N}$ & B & $\mathrm{Cu}$ & $\mathbf{F e}$ & Mn & $\mathrm{Zn}$ \\
\hline & $\mathrm{g} \mathrm{kg}^{-1}$ & & & $-\mathrm{mg} \mathrm{kg} \cdot 1$ & & - \\
\hline $15 \mathrm{~g} \mathrm{ha}^{-1}$ of $\mathrm{Mo}+0.74 \mathrm{~g} \mathrm{ha}^{-1}$ of $\mathrm{Co} \mathrm{CS}^{(1)}$ & $35.8 \mathrm{a}$ & $31.5 \mathrm{a}$ & $10.0 \mathrm{a}$ & $141.0 \mathrm{a}$ & $29.8 \mathrm{a}$ & $24.5 \mathrm{a}$ \\
\hline $25 \mathrm{~g} \mathrm{ha}^{-1}$ of Mo $+1,23 \mathrm{~g} \mathrm{ha}^{-1}$ of $\mathrm{Co} \mathrm{CS}^{(1)}$ & $40.0 \mathrm{a}$ & $30.8 \mathrm{a}$ & $9.5 \mathrm{a}$ & $130.8 \mathrm{a}$ & $39.8 \mathrm{a}$ & $23.8 \mathrm{a}$ \\
\hline $35 \mathrm{~g} \mathrm{ha}^{-1}$ of Mo $+1,72 \mathrm{~g} \mathrm{ha}^{-1}$ of $\mathrm{Co}^{-\mathrm{CS}^{(1)}}$ & $40.3 \mathrm{a}$ & $33.5 \mathrm{a}$ & $10.3 \mathrm{a}$ & $143.8 \mathrm{a}$ & $37.5 \mathrm{a}$ & $26.3 \mathrm{a}$ \\
\hline $45 \mathrm{~g} \mathrm{ha}^{-1}$ of Mo $+2,21 \mathrm{~g} \mathrm{ha}^{-1}$ of $\mathrm{Co} \mathrm{CS}^{(1)}$ & $37.1 \mathrm{a}$ & $30.0 \mathrm{a}$ & $10.3 \mathrm{a}$ & $163.8 \mathrm{a}$ & $32.0 \mathrm{a}$ & $27.0 \mathrm{a}$ \\
\hline $60 \mathrm{~g} \mathrm{ha}^{-1}$ of Mo $+2,95 \mathrm{~g} \mathrm{ha}^{-1}$ of $\mathrm{Co} \mathrm{CS}^{(1)}$ & $39.3 \mathrm{a}$ & $30.8 \mathrm{a}$ & $10.3 \mathrm{a}$ & $119.8 \mathrm{a}$ & $38.8 \mathrm{a}$ & $25.0 \mathrm{a}$ \\
\hline $15 \mathrm{~g} \mathrm{ha}^{-1}$ of Mo $+3,18 \mathrm{~g} \mathrm{ha}^{-1}$ of $\mathrm{Co} \mathrm{SL}^{(2)}$ & $39.1 \mathrm{a}$ & $32.0 \mathrm{a}$ & $10.5 \mathrm{a}$ & $161.8 \mathrm{a}$ & $39.0 \mathrm{a}$ & $28.0 \mathrm{a}$ \\
\hline $20 \mathrm{~g} \mathrm{ha}^{-1}$ of Mo $+4,25 \mathrm{~g} \mathrm{ha}^{-1}$ of Co SL ${ }^{(2)}$ & $44.3 \mathrm{a}$ & $30.3 \mathrm{a}$ & $9.3 \mathrm{a}$ & $141.8 \mathrm{a}$ & $32.0 \mathrm{a}$ & $26.0 \mathrm{a}$ \\
\hline $25 \mathrm{~g} \mathrm{ha}^{-1}$ of Mo $+5,31 \mathrm{~g} \mathrm{ha}^{-1}$ of Co SL ${ }^{(2)}$ & $39.1 \mathrm{a}$ & $29.8 \mathrm{a}$ & $10.3 \mathrm{a}$ & $167.8 \mathrm{a}$ & $31.8 \mathrm{a}$ & $24.5 \mathrm{a}$ \\
\hline Control & $38.2 \mathrm{a}$ & $28.8 \mathrm{a}$ & $10.0 \mathrm{a}$ & $146.3 \mathrm{a}$ & $40.0 \mathrm{a}$ & $28.3 \mathrm{a}$ \\
\hline LSD & 14.92 & 8.86 & 1.71 & 62.41 & 20.45 & 6.85 \\
\hline $\mathrm{CV}(\%)$ & 15.81 & 11.97 & 7.08 & 17.74 & 23.88 & 10.99 \\
\hline
\end{tabular}

(1) CS: concentrated suspension formulation. ${ }^{(2)} \mathrm{LS}$ : Liquid solution formulation. Means followed by the same letter in the column did not differ significantly by the Tukey test at $5 \%$. 
The leaf $\mathrm{N}$ content was below the level recommended by CFSEMG (1999) for soybean in all treatments. Moraes (2006) states that foliar or seed applications of Co and Mo showed no positive effects on the $\mathrm{N}$ concentrations in soybean leaves. Yet, according to CFSEMG (1999), the concentrations of nutrients are appropriate, indicating an adequate nutritional status of soybean, with exception of the treatments with application of $25 \mathrm{~g} \mathrm{ha}^{-1}$ Mo with CS and $20 \mathrm{~g} \mathrm{ha}^{-1}$ Mo with $\mathrm{LS}$ for $\mathrm{Cu}$.

\section{CONCLUSIONS}

1. The doses of Mo and Co in the seed treatment with liquid solution and concentrated suspension increased soybean grain yields.

2 . Soybean yields in the treatments were higher than of the control from rates of $20 \mathrm{~g} \mathrm{ha}^{-1}$ of Mo and $4.25 \mathrm{~g} \mathrm{ha}^{-1}$ of Co in liquid solution and $35 \mathrm{~g} \mathrm{ha}^{-1} \mathrm{Mo}$ and $1.72 \mathrm{~g} \mathrm{ha}^{-1}$ of Co in concentrated suspension and higher.

\section{LITERATURE CITED}

BATAGLIA, O.C.; FURLANI, A.M.C.; TEIXEIRA, J.P.F.; FURLANI, P.R. \& GALLO, J.R. Métodos de análises químicas de plantas. Campinas, Instituto Agronômico de Campinas, 1983. 48p. (Boletim, 78)

BELLINTANI NETO, A.M. \& LAM-SÁNCHEZ, A. Efeito de Mo sobre a nodulação e produção de soja (Glycine max (L.) Meril). Científica, 1:17, 1974.

BUZETTI, S.; MAURO, A.O. \& VARGAS, J.T.D. Efeito de vários micronutrientes na cultura de soja. In: UNIVERSIDADE ESTADUAL PAULISTA. Relatório técnico-científico. Ilha Solteira, 1981. p.66-68.

CAMPO, R.J. \& HUNGRIA, M. Importância dos micronutrientes na fixação biológica do nitrogênio. In: CONGRESSO BRASILEIRO DE SOJA MERCOSOJA, 2., Londrina, 2002. Anais. Londrina, Embrapa Soja, 2002. p.355-366. (Embrapa Soja; Documentos, 180)

COMISSÃO DE FERTILIDADE DO SOLO DO ESTADO DE MINAS GERAIS - CFSEMG. Recomendações para o uso de corretivos e fertilizantes em Minas Gerais. 5a Aproximação. Viçosa, MG, Universidade Federal de Viçosa, 1999. 359p.
EMPRESA BRASILEIRA DE PESQUISA AGROPECUÁRIA EMBRAPA. Centro Nacional de Pesquisa de Soja. Inoculação das sementes com Bradyrhizobium. In: EMPRESA BRASILEIRA DE PESQUISA AGROPECUÁRIA - EMBRAPA. Tecnologias de produção de soja: Região Central do Brasil 2004. Londrina, 2003.

EMPRESA BRASILEIRA DE PESQUISA AGROPECUÁRIA EMBRAPA. Centro Nacional de Pesquisa de Soja. Inoculação das sementes com Bradyrhizobium. In: EMPRESA BRASILEIRA DE PESQUISA AGROPECUÁRIA - EMBRAPA. Tecnologias de produção de soja: Região Central do Brasil 2007. Londrina, 2006.

GUPTA, U.C. \& LIPSETT, J. Molybdenum in soil, plants and animals. Adv. Agron., 34:73-115, 1981.

KOLLING, J.; SCHOLLES, D. \& BROSE, A. Efeito do Mo aplicado em diferentes formulações sobre a nodulação e rendimentos de grãos de soja (Glycine $\max$ (L.) Merril). Agron. Sulriograndense, 17:239-248, 1981.

LAM-SÁNCHEZ, A. \& AWAD, M. Efeito da simazina e do Mo no rendimento, conteúdo protéico e nodulação da soja e da simazina no rendimento e conteúdo protéico do feijoeiro (Phaseolus vulgaris L.). Científica, 4:56-58, 1976.

LANTAMANN, A.F. Nutrição e Produtividade da Soja com Molibdênio e Cobalto. In: CICLO DE REUNIÕES CONJUNTAS DA CESM-PR, PRODUTORES DE SEMENTES, MUDAS”, 20., Londrina, 2002. Palestras... Londrina, Embrapa/CNPSo, 2002.

LOPES, M.E.B.M. \& LEONEL JÚNIOR, F.L. Efeito da aplicação de fungicidas, cobalto e molibdênio em sementes de soja sobre a sanidade, emergência e produtividade da cultura. R. Agric., 75:87-86, 2000.

MARSCHNER, H. Mineral nutrition of higher plants. London, Academic Press, 1986. 674p.

MORAES, L.M.F. Translocação de Co e Mo aplicados em diferentes épocas na cultura da soja. Uberlândia, Universidade Federal de Uberlândia, 2006. 43p. (Tese de Mestrado)

PESSOA, A.C.S.; LUCHESE, E.B.; CAVALLET, L.E. \& GRIS, E.P. Produtividade da soja em resposta à adubação foliar, tratamento de sementes com molibdênio e inoculação com Bradyrhizobium japonicum. Acta Sci., 21:531-535, 1999 .

SFREDO, G. J.; BORKKERT, C. M. \& CASTRO, C. Efeito de micronutrientes sobre a produção de soja em três solos do Estado do Paraná. Inf. Agron., 75:2-3, 1996.

VITTI, G.L.; FORNASIER, D. \& PEDROSO, P.A.C. Fertilizantes com molibdênio e cobalto na cultura da soja. R. Bras. Ci. Solo, 8:349-352, 1984. 